\title{
IRAQ'S POST-ELECTION POLITICAL DYNAMICS: PRESSING CONCERNS AND CONFLICTING AGENDAS
}

\author{
Daniel Barnes ${ }^{1}$ \\ UNISCI
}

\begin{abstract}
:
This paper provides an overview of the current political, social and economic situation in Iraq and analyzes the dynamics of Iraq's political governing body, the Council of Representatives (COR), which was elected to office during the March 2010 national parliamentary elections. Since these elections, Iraqi politics have been marked by political wrangling, infighting and increased polarization, which have negatively affected governance throughout the country. With the U.S. military withdrawal date set for the end of this year, security concerns have also been highlighted. The Iraqi government will soon be handed increased responsibilities in protecting citizens and maintaining stability throughout the country. Furthermore, the recent protests in Iraq during the Arab Spring have shown that even a democratically elected government is not immune to civil unrest if it does not respond to its people's needs. This paper argues that if competing Iraqi political factions continue to put personal interests and political ideologies over effective policymaking, the recent successes in security and democratization throughout the country may be quickly reversed.
\end{abstract}

Keywords: Iraq, Council of Representatives (COR), U.S military withdrawal, Iraqi government, Iraqi political factions, security, democratization.

\begin{abstract}
Resumen:
Este artículo proporciona una visión de la actual situación política, social y económica en Irak y analiza las dinámicas del cuerpo gubernamental iraquí, el Consejo de Representantes (COR), que fue elegido en las elecciones parlamentarias nacionales de marzo de 2010. Desde esas elecciones, la política iraquí ha venido marcada por discusiones politicas, luchas intestinas y una creciente polarización, que ha afectado de forma negativa la gobernanza en el país. Con la salida militar de Estados Unidos, fijada para finales de este año, la preocupación por la situación de seguridad ha sido también remarcada. El gobierno iraqui tendrá pronto que asumir responsabilidades crecientes para proteger a sus ciudadanos y mantener la estabilidad a lo largo del país. Además, las protestas recientes en Irak durante 'la primavera árabe' han demostrado que incluso un gobierno elegido democráticamente no es inmune a las protestas civiles si éste no responde a las necesidades de la gente. El artículo argumenta que si la competencia en las facciones políticas iraquíes continúa situando los intereses personales y la ideología política por encima de las políticas efectivas, los recientes éxitos en seguridad y democratización a lo largo del país pueden ser rápidamente revertidos.
\end{abstract}

Palabras clave: Irak, Consejo de representantes (COR), salida militar de Estados Unidos, gobierno iraquí, facciones políticas iraquies, seguridad, democratización.

Copyright (C) UNISCI, 2011.

Las opiniones expresadas en estos artículos son propias de sus autores, y no reflejan necesariamente la opinion de UNISCI. The views expressed in these articles are those of the authors, and do not necessarily reflect the views of UNISCI.

\footnotetext{
${ }^{1}$ Daniel Barnes is UNISCI Junior Research and Master in International Relations (Universidad Complutense de Madrid).Email: db8908@gmail.com.
} 


\section{Introduction}

The War in Iraq has greatly affected the dynamics of governance and stability within the country. Since the US invasion in March of 2003, Iraq's military has been dismantled and the outbreak of civil war has caused sectarian violence and deep ethno-religious rifts that continue to reverberate today. While the security situation in Iraq has drastically improved in recent years, the country continues to be subject to both internal and external security threats, lack of political cohesion, sectarianism and budgetary limitations that limit basic services throughout the country. Furthermore, several of the "benchmarks" ${ }^{2}$ set in place in 2006 by the US and Iraq, that if adopted and implemented, might achieve political reconciliation, have still not been achieved.

This paper will focus heavily on the makeup of the recently formed, all-inclusive government of Iraq that was democratically voted to power in the March 2010 national elections. The dynamics of the Council of Representatives (COR) - Iraq's parliament - are greatly affecting governance and in turn security throughout the country as US troop presence winds down. Furthermore, external actors and events are playing an increasing role in Iraqi affairs. Increased sectarianism within the COR, the failure to meet Iraqi citizens' demands and still active insurgent groups could lead to an increasingly volatile environment leading up to and after the December 2011 US military withdrawal date.

\section{The Pre-Election Climate Leading Up to the 2010 Parliamentary Elections}

The run-up to the March 2010 Iraqi parliamentary elections was full of uncertainties and would be a preview of the post-election partisan politics and polarization to follow. While the security situation continued to improve, and violent attacks were on the decline, Iraqis and international onlookers feared a repeat of the 2005 elections in which Sunni groups boycotted, leading to the eventual breakout of civil war starting in 2006. Ethno-religious sectarianism continued to run deep throughout the country and several disputes over issues such as the election law which would lay out the ground rules for the election, territorial sovereignty over

\footnotetext{
${ }^{2}$ The 18 benchmarks to gauge "progress" in Iraq as stated in the U.S. Congressional bill H.R. 2206 are as follows:

1. Forming Constitutional Review Committee (CRC) and completing review: 2. Enacting and implementing laws on De-Baathification; 3. Enacting and implementing oil laws that ensure equitable distribution of resources 4. Enacting and implementing laws to form semi-autonomous regions; 5. Enacting and implementing: (a) a law to establish a higher electoral commission, (b) provincial elections law; (c) a law to specify authorities of provincial bodies, and (d) set a date for provincial elections; 6. Enacting and implementing legislation addressing amnesty for former insurgents; 7. Enacting and implementing laws on militia disarmament; 8. Establishing political, media, economic, and services committee to support U.S. "surge"; 9. Providing three trained and ready brigades to support U.S. surge; 10. Providing Iraqi commanders with authorities to make decisions, without political intervention, to pursue all extremists, including Sunni insurgents and Shiite militias; 11. Ensuring Iraqi Security Forces (ISF)

providing even-handed enforcement of law; 12. Ensuring that the surge plan in Baghdad will not provide a safe aven for any outlaw, no matter the sect; 13. (a) Reducing sectarian violence and (b) eliminating militia control of local security; 14. Establishing Baghdad joint security stations; 15. Increasing ISF units capable of operating independently; 16. Ensuring protection of minority parties in COR; 17. Allocating and spending \$10 billion in 2007

capital budget for reconstruction.; 18. Ensuring that Iraqi authorities not falsely accusing ISF members

Source:Katzman, Kenneth: “ Iraq: Politics, Governance, and Human Rights”, Congressional Research Service, 7-5700, 1 April 2011 at http://www.fas.org/sgp/crs/mideast/RS21968.pdf
} 
disputed regions and the on-going debaathification process ${ }^{3}$ remained unsolved. Many analysts believed that these issues showed that Iraq still had a long way to go in reaching political accommodation between the different ethnic and religious sects within the country. Bombings of government ministries by insurgent groups in late 2009 magnified the need for increased security as the US troop withdrawal date of December 30, 2011 lingered in the distance. These disputes and security concerns hampered governance as policy making was sacrificed for political wrangling, and critical problems in providing basic services to Iraqi citizens went unsolved.

Pending approval of a new national election law that would lay out the groundwork and parameters for elections was highly disputed among political factions and Iraqi communities. Passage of the law would be required for the elections to be held. The law would determine key issues such as voter eligibility, possible expansion of the COR, allocation of seats for minorities and women representation and whether to use an open or closed list for the proportional representation system. An open list would allow voters to select one candidate from one political entity for their governorate of residence, while a closed list gives the party the power to determine who occupies actual COR seats after the election. Vetoes and political disputes eventually delayed the national elections which were to be held by January $31,2010 .^{4}$

\subsection{Election Law in Kirkuk}

One of the main reasons for the delay in the elections was the disagreement over the voter rolls in the northern city of Kirkuk. The border disputes over Kirkuk between Arabs and Kurds have gained international attention since the US invasion and the unresolved issues over sovereignty and oil rights have been central in Iraqi political disputes. US troops currently play an integral role in mediating the Arab-Kurd tension in the region and both Kurdish and US officials have expressed increasing concern about the potential for increased violent conflict upon US troop withdrawal.

During the run-up to the 2010 elections, a key dispute was how the election law would be applied to Kirkuk. The question was whether to use the 2005 voter list from the Tamim (Kirkuk) region or the 2009 food rations list. While several COR deputies backed the use of the 2005 list, Kurds feared that this list would leave them underrepresented. They argued that Saddam Hussein had tried to "Arabize" Kirkuk by forcing Kurds out of the city and resettling Arabs in their place, leaving Kurds disenfranchised and underrepresented. The issue continues to be highly politicized. Arabs and Turkmen have argued that the recent massive influx of Kurds into the region by far outweighs the effects of Saddam's "Arabization" policy and gives Kurds an unfair advantage in the national elections. ${ }^{5}$ The Kirkuk election law dispute highlights the need for a new national census that would increase civilian representation and transparency; however, the debate over a new census is currently being held up in the COR and it is not certain when legislation will be passed on the issue.

\footnotetext{
${ }^{3}$ As described in the Coalition Provisional Authority Order Number 1: De-ba'athification of Iraqi Society, on April 16, 2003 the Coalition Provisional Authority disestablished the Ba`ath Party of Iraq. This order implements the declaration by eliminating the party's structures and removing its leadership from positions of authority and responsibility in Iraqi society. Source: http://www.iraqcoalition.org/regulations/20030516_CPAORD_1_DeBa_athification_of_Iraqi_Society_.pdf

${ }^{4}$ Katzman, Kenneth: "Iraq: Politics, Elections and Benchmarks", Congressional Research Service, 14 January 2011 at http://www.fas.org/sgp/crs/mideast/RS21968.pdf

${ }^{5}$ Cordesman, Anthony; Derby, Elena: “The Uncertain Politics Behind Iraq's Election”, Center For Strategic and International Studies, 14 April 2010
} 


\subsection{De-baathification}

The Kurds were not the only group with grievances during the pre-election period. In early January, 2010, the Supreme National Commission for Accountability and Justice (the successor to the "De-Baathification Commission") disqualified more than 500 candidates because of alleged links to Saddam Hussien's Ba'ath party. This list included several prominent Sunni and secular Shia politicians that were expected to fare well in the elections. The Commission was headed by Ali al-Lami, a Shia who is part of the National Alliance slate, leading many to believe that the decision was an attempt to keep prominent Sunnis off the ballots. While Ali al-Lami argued that the disqualifications were based on law and careful evaluation of candidate backgrounds and not based on sect, several international analysts and organizations spoke out against the bans and called it a considerable blow to the elections' credibility. Humans Rights Watch (HRW) published a report calling for a revision of the law that would require the Commission to make available evidence against those it seeks to ban. HRW also stated that the Commission should appoint officials based on competence and professional integrity, rather than political loyalty of sectarian affiliation. ${ }^{6}$

The debaathification process is perhaps one of the most telling signs of political manipulation and the increased polarization that is having lasting effects on Iraqi governance. Many Iraqis see the process to be politically motivated and consider the Supreme National Commission for Accountability as illegitimate. Several politicians question whether the decisions made by the commission are even binding or legal. Anthony Cordesman, an Arleigh A. Burke Chair in Strategy at the Center for Strategic and International Studies - and one of the leading experts on the Iraq War - called the recent dismissal of the 500 candidates "the worst legacy of pre-election politics. ${ }^{7}$

\subsection{Pre-Election Security Threats}

In accordance with the Status of Forces Agreement that implements the security relationship between the US and Iraq, on August 31, 2010, US forces formally ended combat missions and began to withdrawal from major populated areas. By December 31, 2010, the overall level of violence in Iraq was nearly $90 \%$ lower than at its peak in 2007 . Nevertheless, a string of bombings reminded Iraqis that their country was far from secure and that insurgents still had an agenda with elections near and US troop withdrawal on the horizon. On August 25, 2010, at least 50 people were killed in a series of apparently coordinated bomb attacks across Iraq in seven different cities. Both US and Iraqi security officials said that the Islamic State of Iraq, a branch of Al Qaeda, was behind the attacks and that it was clearly an attempt to destabilize Iraqi security forces. Many correlated the delays and political disputes over the election law with the high-profile attacks carried out by insurgent groups in an effort to undermine the government. $^{8}$

\subsection{Arriving to an Agreement on the Election Law}

After failing to meet several self-imposed deadlines, on December 6, 2009, the major Iraqi political factions approved a new election law. According to the new law, the national elections would take place on March 7, 2010 and use an open list election system. The

\footnotetext{
${ }^{6}$ Iraq's 2010 national elections, Human Rights Watch 25, February 2010, at http://www.hrw.org/en/news/2010/02/25/iraq-s-2010-national-elections

${ }^{7}$ Cordesman and Derby, op cit., p. 25

${ }^{8}$ Sykes, Hugh: "Dozens Killed in Wave of Bombings Across Iraq", BBC, 25 August 2010 at http://www.bbc.co.uk/news/world-middle-east-11081603
} 
Council of Representatives would be expanded to 325 seats from the previous 275 and no separate constituency for Iraqis in exile would be established. Exiles and displaced persons would have their votes counted in their province of origin. ${ }^{9}$ In regards to Kirkut, the 2009 voter registration list would be used in which Parliament would then review the results after the election to determine whether the number of voters of a particular sect in any given district seemed suspiciously high. ${ }^{10}$ The new law also included 15 compensatory seats, eight at-large seats for Christians and seven seats that would be distributed by the top election winners. $^{11}$

The political infighting and the failure to arrive to a consensus that delayed the passing of the election law highlighted the deep rifts in Iraq politics. Legislation stagnated and services went undelivered. Furthermore, the agreement over the election law would most likely not have been possible if it were not for the brokering and intervention of the U.S. and the UN.

\section{Election Results and Implications}

The March 7, 2010 national parliamentary elections showed a larger than expected voter turnout of $62 \%$, and unlike previous elections, all major ethnic and religious factions participated. With drastic security measures and election-week curfews in place, the majority of Iraqis were able to get to the polls. Sam Dagher, a New York Times reporter based in Kirkut during the elections, stated that election day was exceptionally peaceful given the extraordinary security measures that were taken and the heavy presence by U.S. troops. Blasts did take place in Baghdad and other cities; however, even in Fallujah, a city synonymous with militancy and anti-American rhetoric, citizens made their way to the polls to cast their votes. ${ }^{12}$

The elections resulted in near parity between the secular, Sunni-led Iraqiyya list, and the Prime Minister, Nouri al-Maliki's, nationalist, Shia dominant State of Law (SOL) Coalition. The Iraqi National Movement (Iraqiyya) won the most seats with 91 over Maliki's State of Law coalition, which came in second with 89 seats. The National Iraqi Alliance won 70 seats and the Kurdistan Alliance 43 seats. Although Iraqiyya came out the winner in parliamentary seat numbers, the party lacked the sufficient support to choose a prime minister and appoint ministerial positions. The winning coalition needed to obtain at least 163 parliamentary seats to form a government. According to the Iraqi constitution, the bloc with the largest coalition at the time that parliament is seated has 30 days to try to form a ruling coalition and if they are unsuccessful, the second-largest coalition will try and so on. ${ }^{13}$

\footnotetext{
${ }^{9}$ Katzman, Kenneth: "Iraq: politics, elections and benchmarks", Washington: Congressional Research Service, 14 January 2011 at http://www.fas.org/sgp/crs/mideast/RS21968.pdf

${ }^{10}$ Williams, Timothy: "Iraq Passes Crucial Election Law", The New York Times, 8 November 2009 at http://www.nytimes.com/2009/11/09/world/middleeast/09iraq.html

${ }^{11}$ Cordesman \& Derby, op. cit., p. 10

12 Dagher, Sam: "At war blog", The New York Times", 21 April 2010

${ }^{13}$ Cordesman and Derby, op cit, p. 10
} 


\section{Coalition Formation and Political Alliances}

The March 7, 2010 elections kicked off a new phase in Iraqi politics. Without a dominant party that could form a government, the major political factions scrambled to form coalitions that would give them the proper leverage to obtain the necessary 163 parliamentary seats. During this time, major shifts began to take place within past parties and a number of smaller parties and first-time candidates emerged. Newcomers began to challenge incumbents and several politicians abandoned past alliances in favor of forming more secular creations in an attempt to increase their appeal. A new political trend was underway that several analysts have deemed the "emergence of nationalist politics." In short, this consists of political parties putting national concerns such as basic services and security over ethno-religious motivations. This was seen primarily within Iraqiyya - a faction that is led by a Shia but appeals largely to Sunnis - and can also be seen in Prime Minister Maliki's recent political manoeuvres. Even Moqtada Al-Sadr's Sadrist Trent, a movement synonymous with hard-line stances, has incorporated nationalist rhetoric into recent political speeches. ${ }^{14}$ The political wrangling and coalition formation process that followed, which will be described in detail shortly, proved to have adverse effects on Iraqi governance and stability throughout this period.

The following provides a quick glimpse at the major Iraqi political alliances and the recent changes that they have undergone:

\subsection{Major Iraqi Political Coalitions ${ }^{15}$}

State of Law (SOL): On October 1, 2009, current Prime Minister Nouri al-Maliki announced that he and his Dawa party would split from the United Iraqi Alliance (UIA) - the Shia coalition that named him Prime Minister in 2005 - to form the nationalist State of Law Coalition. Campaigning as a secular, Maliki gained support from individuals and relatively small ethnic and religious organizations in joining the alliance. However, he has failed in winning over major personalities and groups to make the coalition truly secular and has not won over any Kurdish groups other than the small United Independent Iraqi Bloc, which represents Shia Kurds, a small minority. SOL currently heads 12 ministerial departments including four very important ones: Security; Interior; National Security and Oil. Analyst note that its success will depend heavily on Maliki's success as a leader and provincial and local leaders' ability to provide services to their constituencies.

Iraqi National Alliance (INA): Iraqi National Alliance is the successor of the United Iraqi Alliance, which has dominated the government since the December 2005 elections. The alliance changed its name after Dawa's withdrawal in 2009 and now is comprised of the Islamic Supreme Council in Iraq (ISCI), the Badr organization, the Sadrist movement, the Virtue Party (Fadilah), and smaller Shia religious groups. The INA has attempted to reach out to both Sunni and Kurd parties; however, with little success. The majority of its representational leaders are Islamist Shia. Both the Badr organization and the Sadrist movement are attempting to clean their malicious images and convince the public that they are able political entities. This will be explored to a greater extent further in the article. The INA and its members control a number of service-sector ministries such as Housing, Resources, and Justice and will be put to the test in improving Iraq's service shortfalls.

\footnotetext{
${ }^{14}$ Ibid.p. 18; Katzman, op. cit., p. 13

${ }^{15}$ The information in this sections can be found at: "Iraqi Elections 2011". Carnegie Endowment for International Peace, 2010 at

http://www.carnegieendowment.org/publications/special/misc/iraqielections2010/\#partyAlliances
} 
The Iraqi National Movement (Iraqiyya): The Iraqi National Movement is the major secular, non-sectarian political movement in Iraq. Its key members are the Iraqi National Accord (Secular Shia) - headed by former Prime Minister Iyad al-Allawi - the Iraqi Front for National Dialogue (Secular Sunni) and the Renewal List (Sunni). The movement largely relies on the strong political personalities of the leaders of these groups. Iraqiyya won a plurality of votes in the March elections, but not enough to form a new government. Several of its candidates were banned from running for political office by the Supreme National Commission for Accountability and Justice due to their former ties to Saddam Hussein's Ba'ath Party; however, they continued to actively campaign for the party. While the party is under Shia leadership, it managed to obtain votes across sectarian lines by focusing more on policy than ethnicity and addressing pressing security and development issues rather than seeking ethnic and sectarian appeal. The alliance between Allawi and Saleh al-Mutlaq, leader of the Iraqi Front for National Dialogue, is based on pragmatic politics as opposed to ethnic identity. Allawi appeals to the sectarian electorate while Mutlaq plays the nationalist card. ${ }^{16}$

The Kurdish Parties: There are three major Kurdish parties: the Kurdish Democratic Party (KDP), the Patriotic Union of Kurdistan (PUK), and Gorran (Movement for Change). The $\mathrm{KDP}$ and the PUK are well established and have advocated for Kurdish rights by voting in a unified block. Together they form what is referred to as the Kurdistan Alliance. 2009 marked a shift in Kurdish politics with the emergence of the Gorran party. Gorran ran its own separate list which constituted a significant challenge to the Kurdistan Alliance in Sulaymaniyah Province. As a result, of the 57 COR seats held by Kurds, 14 are held by parties other than the the KDP and PUK. Gorran has 8, the Kurdistan Islamic Union has 4, and the Islamic Group of Kurdistan has $2 .^{17}$

\section{Difficulties of Arriving to an Agreement}

The large voter turnout for the March elections and the near parity between the two major political parties, State of Law and Iraqiyya, was lauded by the international community as all major ethnic factions turned out to vote. However, the close results were also cause for immediate concern. A June 2010 US Department of Defense report to Congress opened by stating, "Although these results reflect a maturing political identity among the Iraqi people, the lack of a dominant bloc means a slow path toward government formation that will likely continue into and perhaps beyond the summer." 18 The government formation process proved to be slow and complex as expected, displaying the ever-present sectarianism and personal interests that guide Iraqi politics and undermine governance. The eight-month stalemate was referred to by one New York Times correspondent as "utter political dysfunction." This feeling was shared both by many Iraqis and the international community as politicians delayed the formation process while Iraqi citizens suffered. Legislation was stalled, basic services declined, and needs went unaddressed. ${ }^{19}$

\footnotetext{
${ }^{16}$ Cordesman \& Derby, op cit., p 17

${ }^{17}$ Katzman, op cit., p. 12

${ }^{18}$ US Department of Defense: "Measuring Stability and Security in Iraq", US Congress, Committee on Foreign Relations (June 2010) at http://www.defense.gov/pubs/pdfs/June_9204_Sec_Def_signed_20_Aug_2010.pdf

${ }^{19}$ Shadid, Anthony: "Iraq's Last Patriot", The New York Times, 4 February 2011 at http://www.nytimes.com/2011/02/06/magazine/06ALLAWI-t.html
} 
The summer of 2010 was long and especially hot given the governments inability to address dire electricity shortages throughout the country. Without a representative government, Iraqis looked on as their elected representatives engaged in political infighting, bargaining and postponements. The key issue was who would gain enough support to form the representative government of 163 parliamentary seats. The 2005 Iraqi Constitution gives that right to "the largest parliamentary bloc." Secular Sunni former Prime Minister and Iraqiyya leader, Iyad Allawi, won the most parliamentary seats and therefore believed that he should be in charge of forming a new government.

However, in an attempt to hold on to the coveted Prime Minister position, Nouri alMaliki challenged the results in the courts by leading a campaign to disqualify several Iraqiyya winning candidates on the grounds that they had ties to the banned Ba'ath Party. This would set the stage for sectarian based maneuvering, increased polarization and political stalling which all negatively affected Iraqi governance during political stalemate. Maliki argued that the phrase "largest parliamentary block" refers not to the list that wins the most votes in the election, but to the post-election bloc that is largest at the moment the new parliament is seated. Given that Shias form the majority of the COR, this would ensure that the Prime Minister would always be Shia. ${ }^{20}$

\subsection{Courting the Kurds}

The Kurds have historically enjoyed the role of "kingmaker" in exchange for heavy concessions. This stood true in 2010 as the major Kurdish parties showed no desire to join non-sectarian alliances during the parliamentary elections. With 57 COR seats, the Kurds opted to court both State of Law and Iraqiyya, saying that they would support any nominee who would accept their nineteen demands, which aimed at strengthening the autonomy of the Kurdish region and holding a referendum in Kirkuk in hope of annexing it to the Kurdish region. ${ }^{21}$ Other demands, reiterated by the Kurds for years, related to the long-stalled hydrocarbons law and further legal and institutional reform, as well as increased Kurdish representation in state institutions. ${ }^{22}$

Both Maliki and Allawi publicly acknowledged the Kurds' critical role in forming the government. Relations between Iraqiyya and the Kurds had been marked with suspicion throughout the past as the Sunni nationalist element of Iraqiyya has often openly opposed Kurdish autonomy. However, both groups now found themselves in a relationship of mutual need. Iraqiyya needed Kurdish support to form a government and the Kurds needed the support of Iraqiyya if they wanted to maintain hope in tackling issues regarding disputes over Kirkut where there are mixed areas of Arabs (many of which make up Iraqiyya's contstituency) and Turkmen along the border of Kurdistan. Meanwhile, Maliki stated that he was willing to satisfy most Kurd demand in exchange for their support. Allawi was less willing to concede publicly and accused Maliki of making empty promises. ${ }^{23}$

\footnotetext{
${ }^{20}$ The information in this paragraph was drawn from: Hiltermann, Joost: "Iraq's Summer of Uncertainty", The New York Times, 4 June 2010 at http://www.nybooks.com/blogs/nyrblog/2010/jun/04/iraqs-summeruncertainty/

${ }^{21}$ Kaysi, Danial: “Iraq: Movement Without Progress”, Carnegie Endowment for International Peace, 18 October 2010 at http://carnegieendowment.org/publications/?fa $=41743$

${ }^{22}$ International Crisis Group: "Iraq and the Kurds: Confronting Withdrawal Fears", Middle East Report No 103 , 28 March 2011

${ }^{23}$ Kaysi, op cit., p 2
} 


\subsection{The Return of Muqtada Al Sadr}

Shia cleric Moqtada Al Sadr is perhaps the most clear example the COR's new identity. Al Sadr began making international headlines after the toppling of the Hussein regime as his fiery public speeches called for the immediate withdrawal of US led coalition forces. In 2006, as his Mahdi Army led the charge in a sectarian civil war by targeting both Sunni and Coalition forces, the International Crisis Group stated that Sadr was now a key to Iraqi stability and must be treated in such a way. In the newly formed Iraqi government, Al Sadr's Islamic Supreme Council of Iraq occupies 40 parliamentary seats, which made his support essential for both Maliki and Allawi in their race to 163 seats. ${ }^{24}$

While Sadr vowed to convert his street movement into a political force, questions remained over how his ascension to power would affect sectarian tensions throughout the county. Just years before, thousands were victims of the violence carried out by Sadr's militia. It would also later be revealed that in return for Sadr's support, Maliki brokered a deal that found over 600 imprisoned individuals (who were believed to be Sadrists) innocent of the violent crimes they were charged with and released from prisons. While the government denies a deal was made, many Iraqis believe otherwise. ${ }^{25}$ Sadr and his followers will continue to play a key role in Iraqi governance, a topic which will be explored further along in this paper.

\subsection{Political Stagnation and Brewing Discontent}

A lack of a dominant party led to a nine-month political impasse in which Iraqi civilians suffered while politicians wrangled for power. Politicians had campaigned on promises of improving basic services such as electricity, running water and sewage; however, delivering these services to the public took a back seat to political maneuvering and sectarian interests. The impasse resulted in legislative stagnation as little tangible progress was made on key legislative issues, causing cuts in social spending on programs like welfare and unemployment. By the summer of 2010, many Iraqis grew tired of the government's incompetency in providing basic needs. Civil unrest began to spread and many blamed corruption for the shortcomings. Most Iraqis only received four to five hours of electricity a day from the Iraqi national electric grid a day. This led to health concerns as hospitals were forced to rely on generators and cases of heat stroke and dehydration skyrocketed among young civilians. In the southern cities of Nasiriyah and Basrah public anger over electricity shortages led to street protests where police responded violently at times. Water cannons were used in Nasiriyah and two were killed in Basrah when police opened fire into the crowd. $^{26}$

By late November 2011, Iraq's leaders had met only four times since the March elections. On Sunday, November 20, 2010, the new speaker of Parliament, Osama al-Najafi, stated that he had received a letter from the government admitting it no longer had enough money to make welfare payments to widows, the unemployed and needy Iraqis and that the

\footnotetext{
24 “Iraq's Muqtada Al-Sadr: Spoiler or Stabiliser?”, International Crisis Group, 11 July 2006 at http://www.crisisgroup.org/ /media/Files/Middle\%20East\%20North\%20Africa/Iraq\%20Syria\%20Lebanon/Iraq/ 55_iraq_s_muqtada_al_sadr_spoiler_or_stabiliser.ashx

${ }^{25}$ Ottaway, Marina; Kaysi, Danial: "Winners and Losers in the Iraqi Election Battle", Carnegie Endowment for International Peace, 10 January 2011 http://www.carnegieendowment.org/publications/index.cfm? fa=view\&id=42260

26 "In Iraq, Electricity Remains Daily Struggle for Families, Businesses", Public Broadcasting Station, 3 September 2010. http://www.pbs.org/newshour/bb/middle_east/july-dec10/iraq_09-03.html
} 
government would not be able to resume that aid until a new budget was passed. ${ }^{27}$ Iraq has been in a budget crisis since 2009 that has resulted in freezes and cuts in public spending in several sectors. The failure to meet civilian demands for services continues to be one of the major challenges to the politically divided Iraqi government and continued civilian anger could prove to be the most serious threat to the nascent and fragile Iraqi political system.

\section{Outsider Intervention and Influence}

The political stalemate gained increased attention from the international community as it dragged on and fears began to arise over the future of democracy Iraq. Both the US and Iran would prove to be key players throughout the government formation process. Nevertheless, Prime Minister Maliki insisted that Iraq will maintain strong relationships with the United States, Iran, Turkey and its Arab neighbors without entering into strict alliances that will jeopardize the country's interests. ${ }^{28}$ Many prominent Iraqi politicians were at one time politically exiled under the Saddam Hussein's regime and therefore hold strong ties with the countries where they sought asylum. Unfortunately, these countries often have conflicting interests in influencing Iraqi politics.

While Maliki vows to combat foreign meddling in Iraqi politics, analysts have noted that playing the non-alignment card when stuck between two powers (in this case the US and Iran) with conflicting interests is often times difficult. ${ }^{29}$ Recently leaked US diplomatic cables revealed by the anti-secrecy organization, Wikileaks, portray Baghdad's current frustration with foreign interference. “All Iraq's neighbors were interfering, albeit in different ways, the Gulf and Saudi Arabia with money, Iran with money and political influence, and Syrians by all means," Iraq's President and the senior Kurdish official, Jalal Talabani, told Defense Secretary Robert M. Gates in a December 10, 2009 meeting. ${ }^{30}$

\subsection{US Involvement in Iraqi Government Formation}

Since 2005, the US has pushed for an Iraqi government that represents all ethnic and religious factions in the country. Holding provincial elections has been one of the key objectives and benchmarks established by the US to measure political progress in Iraq. Because Sunnis mostly boycotted the December 2005 provincial elections, local governments have been primarily dominated by Shias in the south and center of the country and Kurds in the north. ${ }^{31}$ Reversing this process has been one of Washington's key objectives in an attempt to increase Sunni participation and counter Shia dominance throughout the government. Furthermore, an inclusive governing body with significant Sunni Arab participation would counter Iranian influence in backing pro-Iranian Shia military factions in Iraq and reduce Tehran's influence

\footnotetext{
${ }^{27}$ Healy, Jack; Yasir Ghazi: “Iraqi Leaders Delay New Government”, The New York Times, 21 November 2010 at http://www.nytimes.com/2010/11/22/world/middleeast/22iraq.html

28 “Transcipt: Maliki on Iraq's Future," The Wall Street Journal, 28 December 2010 at http://online.wsj.com/article/SB10001424052970203513204576047804111203090.html

${ }_{29}$ Ottaway, Marina: "Iraq: An Uneasy American-Iranian Condominium", Carnegie Endowment for International Peace, 10 January 2011

${ }^{30}$ Gordon, Michael: "Meddling Neighbors Undercut Iraq Stability", 5 December 2010,

http://www.nytimes.com/2010/12/06/world/middleeast/06wikileaks-iraq.html

${ }^{31}$ Beehner, Lionel; Bruno, Greg: "What are Iraq's Benchmarks?”, Council on Foreign Relations, 11 March 2008
} 
in the Iraqi political arena. Washington's desire to counter Iranian influence has become increasingly clear as the December 2011 US troop withdrawal date nears. ${ }^{32}$.

\subsection{The Iranian Factor}

With long-time enemy Saddam Hussein out of the picture, Iran immediately sought to extend its influence throughout neighboring Iraq. In early December 2002, during the run-up to the US invasion, exiled Iraqi opposition leaders met in Tehran as a prelude to the Iraqi opposition conference that would be held in London the following week. Several of these exiled Shia leaders such as Abdul Aziz al-Hakim, who would eventually preside over the Iraqi Governing Council, held strong ties with the Islamic Republic. The purpose of the meeting in Tehran was to caucus their strategy in a post-Saddam Iraq. According to former Senior U.S. State Department Advisor to Iraq, David Phelps, "This was when the U.S. government recognized for the first time that a lot of these Iraqi Shia groups were much more beholden to Tehran than they were to us (the US).",33

Iraq is of great importance to Iran not just in strategic importance to expand its influence throughout the Middle East, but for cultural and ideological reasons as well. The Shia religion has its roots in southern Iraq where holy shrines of saints that defined the religion are located. When Saddam's regime was toppled, Iran opened its border and millions of Iranian Shia pilgrims flooded into southern Iraq to visit these holy shrines. The massive movement was later deemed the "Shia Revival". The Bush administration never anticipated such an event given the two countries' conflictive past. This also deeply worried Iraq's Arab neighbors. "Not only did Iran have better intelligence than the US and greater connections with Iraqi militias, but it also had the good will of the people," stated Vali Nasr, professor and author of The Shia Revival. In Iraq's first free elections in 2005, Iran helped Iraqi Shia to get out the vote and was successful in seeing their allies come to power. For the first time, Shia governed an Arab state. ${ }^{34}$

\subsection{Saudi Arabia}

Historically, a strong and stable Iraq under Saddam Hussein's rule was a threat to the Saudi Arabia and its Arab neighbors. However, a strong Iraqi state also served as a buffer to a greater rival: Iran. When the US decided to invade Iraq, Saudi Arabia (along with several other Arab countries) supported the effort. But with a sectarian civil war breaking out shortly after the US invasion, and the inevitable future of a Shia-dominated Iraqi government with ties to Tehran in the distance, the Saudi Kingdom began to take action.

Riyadh has increased its political influence throughout the Middle East and particularly in Iraq in recent years. The leaked US State Department file titled "The Great Game in Mesopotamia," shows Maliki's fears of Saudi interference being so great that he asked President Barack Obama during a July 2009 visit to Washington to stop the Saudis from intervening in Iraqi politics which "would give Iran an excuse to intervene also." According to another file, after a meeting in Ankara in February 2010, Feridun Sinirlioglu, a

\footnotetext{
${ }^{32}$ In a January 2011, John Kerry, US Senator and Chairman of the US Senate Committee on Foreign Relations stated in the introduction of a letter to the Committee that, "The success of our diplomatic mission there will be an important factor in whether Iraq emerges from years of turmoil as a strategic partner or turns toward Iran." At "Iraq: The Transition From a Military Mission to a Civilian-Led Effort", Committee on Foreign Relations United States Senate, 31 January 11 at http://www.fdsys.gpo.gov

33 “Showdown with Iran”, Public Broadcasting Station (Frontline), 23 October 2007 at http://www.pbs.org/wgbh/pages/frontline/showdown/ ${ }^{34}$ Ibid
} 
senior Turkish Foreign Ministry official, told an American envoy that "Saudi Arabia is 'throwing around money' among the political parties in Iraq because it is unwilling to accept the inevitability of Shia dominance. The US ambassador to Iraq, Christopher Hill, was also reported saying that the Saudis are using their financial and media resources to support Sunni political aspirations, exert influence over Sunni tribal groups, and undercut the Shia Islamic Supreme Council of Iraq and the Iraqi National Alliance. ${ }^{35}$

\subsection{Turkey $^{36}$}

Ankara has drastically stepped up involvement in neighboring Iraq in recent years, shifting from a unilateral military presence in the country to an increasingly economic one. The governing Justice and Development Party's (AKP) policy of "zero problems with neighbors" has resulted in normalized relations with all major Iraqi political blocks, and a series of soft power measures has allowed Turkey to deepen its cultural, educational and business ties throughout the country. In the past, Ankara would largely surpass the bordering Kurdish Regional Government and deal directly with Baghdad when dealing with issues in Kurdistan; however, this has changed in recent years as Turkish officials now engage directly with the KRG and have a consulate set up in the Kurdistan capital of Erbil.

Economic integration and geopolitical gains are at the forefront of Turkey's foreign policy towards its southern neighbor. Ankara sees Iraq as key to its energy objectives and economic influence in the region. Given Turkey's strategic location, and with the planned Nabucco natural gas pipeline that would link Turkey with Austria and provide Europe with an alternative to Russian gas, the country has ambitions to soon be the energy hub linking Europe to the East. Years of war, lack of investment and pending legislation regarding oil rights have left Iraq with vast oil reserves that have barely been exploited. Furthermore, Iraq's natural gas sector is believed to contain significant untapped resources which the Government of Iraq would like to develop for domestic consumption and export. ${ }^{37}$ Ankara is anxiously waiting for the contentious hydrocarbon laws to pass so that Turkish energy companies can resume production throughout Iraq.

Trade and investment has been another key pillar in recent Turkish-Iraqi relations. Cross-border commerce has skyrocketed in recent years between the two countries, and Turkey has invested especially heavily throughout the Kurdistan region. In 2010, trade reached as high as $\$ 6$ billion (twice that of 2008), and Turkish officials have stated that Ankara will push for greater border mobility in the future and make the country Turkey's main trading partner. Currently, more than half of all foreign firms in Kurdistan are Turkish as Turkey sees the region as a "bridge" to the Iraqi market.

\footnotetext{
${ }^{35}$ Tisdall, Simon: "WikiLeaks cables: Saudi Arabia rated a bigger threat to Iraqi stability than Iran", The Guardian, 5 December 2010, http:/www.guardian.co.uk/world/2010/dec/05/wikileaks-cables-saudi-meddlingiraq

${ }^{36}$ The majority of the information from this section comes from two sources: Fielding-Smith, Abigail: "Turkey finds a gateway to Iraq," The Financial Times, 14 April 2010; Weitz, Richard: “Turkey's Influence in Iraq," The Turkey Analyst, vol. 4 no. 2, 24 January 2011.

37: "Iraq: Country Analysis Brief", U.S. Energy Information Administration, 14 July 2010 at http://www.eia.doe.gov/countries/country-data.cfm?fips=IZ
} 


\section{The November 11th Agreement}

During the nine-month impasse, Washington preceded with extreme caution as it did not want to be seen as an influential actor in the process. However, by late summer 2010, upon Iraqi request, the US boosted diplomatic efforts in an attempt to push through an agreement. Advocating inclusiveness, and with Maliki clearly in the lead for the PM position, reports revealed that President Obama personally asked Kurdish leaders to cede the presidency to Iyad Allawi. However, the Kurds immediately refused, accusing Washington of attempting to "hand-pick" Iraq's leaders. ${ }^{38}$

On November 10, 2010, President Obama, with backing from the Kurds, phoned Allawi to ask his support in backing Maliki in a second term as prime minister and Kurdish leader Jalal Talabani as president. Obama assured Allawi that his party would head the newlyformed National Council for Higher Strategic Policies that would have real executive power. At the same time, Tehran quietly convinced Moqtada Al Sadr's Sadrist Trend - the strongest Shia party resisting Maliki's leadership - to back the Prime Minister. This maneuvering allowed Maliki to secure the 163 seats to form a government. ${ }^{39}$

Finally, on November 11, 2011, Prime Minister Nouri al-Maliki, Kurdistan President Massoud Barzan, and the head of the Iraqiyya coalition, Iyad Allawi, came together to sign an agreement that would start the process of choosing ministerial positions within the COR. This would include all major parties and give representation to all major confessional and ethnic groups. The COR met and soon after elected its speaker, Osama al-Nujeifi, his two deputies, and the president, Jalal Talabani, who then asked Maliki to form the new government. The prime minister would then have 30 days to form a cabinet with approval of the Council of Representatives. Under this agreement, government position had to be apportioned among all major population groups and establish which confessional group is entitled to the control of certain positions. Much like the previous government, Shia would control the post of Prime Minister, Kurds the presidency, and Sunnis the post of speaker of the Council of Representatives. ${ }^{40}$

However, the joy was short-lived and the realities of Iraq's turbulent political makeup were seen just three hours into the parliamentary session approving the government. Iyad Allawi and two-thirds of his political block walked out after failing to force a vote on demands that included a release of detainees and the failure to reverse a decision that disqualified three of their candidates previously loyal to the Ba'ath party. A previous verbal agreement required that the COR reverse the decision made by the Justice and Accountability Commission on the three candidates before the president was to be named. This did not happen, and the walkout ensued. Questions immediately arose in respect to the viability of the new government. The event showed the incredible fragility that will underscore Iraqi politics in the near future. ${ }^{41}$

\footnotetext{
${ }^{38}$ Rogin, Josh: "Was Obama's Iraq Intervention a Success or Not?”, Foreign Policy, 11 November 2010 at http://thecable.foreignpolicy.com/posts/2010/11/11/was_obama_s_iraq_intervention_a_success_or_not

${ }^{39}$ Ibid., p. 1

${ }^{40}$ Ottaway, Marina; Kaysi, Daniel: “Can Iraq’s Political Agreement be Implemented?”, Carnegie Endowment for International Peace, 15 November 2010

${ }^{41}$ Myers, Steven Lee: “Allawi Supporters Walk Out of Iraqi Parliament”, The New York Times, 11 November 2010
} 


\section{Winners, Losers and New Realities}

Most analysts consider Maliki to be the big winner in the government formation process as he consolidated his power by holding onto key ministerial positions. The incumbent prime minister will continue as commander and chief of the armed forced and since three crucial ministries - defense, interior, and national security - do not have ministers at present, he directly controls them as well. Moqtada Al Sadr's role as a politician has also been strengthened as his party currently fills 40 parliamentary seats and heads several key ministries, most of which are in the service sectors. Many consider the agreement a big setback for Allawi as he lost out on the prime minister position and the compromise solution that awarded him leadership of the newly formed National Council for Higher Strategic Policies will likely be of little significance. ${ }^{42}$

In a November $20^{\text {th }}$ letter to the New York Times, Vice President Joseph Biden commended Iraqi efforts in forming a new all-inclusive government and described the current situation and what must be done by the US, Iraq and its allies. Biden states that Iraqi security forces have made great strides in recent year; however, they are not yet ready to take on full responsibility and continued US assistance will be necessary. According to Biden, the US must continue to assist Baghdad in integrating Sunnis and Kurds into security forces and help resolve the Kirkuk disputes. The passing of critical hydrocarbon laws and helping Iraq foster private development and pass a national budget will also be on Washington's agenda. To do so, the US Vice President will ask Congress to fulfil budget requests as it is now in Washington's best interest to preserve the gains Iraq has made, prevent the re-emergence of violent extremists and encourage Iraq to be a pivotal U.S. ally in the region. ${ }^{43}$ Given the ideological divides and increased polarization within Baghdad, U.S. officials and their Iraqi counterparts will no doubt have their hands full in accomplishing the above.

According to most experts, the key U.S. objectives appear to have been met in large part because of the inclusion of senior Iraqiyya figures in high government positions. ${ }^{44}$ Nevertheless, the new realities in US-Iraqi relations were exposed during the government formation period. Washington will no longer be able to direct Iraqi politics; instead, it will attempt to quietly influence Iraqi politicians from the periphery. Also, given Tehran's increased influence over Iraqi policy makers, Washington is no longer the only player in the game. Some suggest that the Islamic Republic would have preferred a candidate from the more Islamist Iraqi Supreme Islamic Council over Maliki; ${ }^{45}$ however, Tehran's ties with the increasingly popular Moqtada Al Sadr will no doubt help Iran counter Washington's policies toward Baghdad. Lastly, relations between Maliki and his Saudi neighbors have further digressed. When Maliki was finally awarded the Prime Minister position and the right to form a government, Riyadh did not congratulate the returning prime minister. ${ }^{46}$ As a sign of increased tensions, Maliki recently praised the mainly Shia protesters in Bahrain for lashing out against the government and criticised Saudi Arabia for helping to suppress them on behalf

\footnotetext{
42 Ottaway, Marina; Kaysi, Danial: "Winners and Losers in the Iraqi Election Battle”, Endowment for International Peace, 10 January 2011 at http://www.carnegieendowment.org/publications/index.cfm?fa=view\&id=42260

${ }_{43}$ Biden, Joseph: "What We Must Do For Iraq Now", The New York Times, 20 November 2010.

${ }^{44}$ Rogin, Josh: Was Obama's Iraq Intervention a Success or Not?", Foreign Policy, 11 November 2010 at $\mathrm{http}: / /$ thecable.foreignpolicy.com/posts/2010/11/11/was_obama_s_iraq_intervention_a_success_or_not

${ }^{45}$ Ottaway and Danial, op cit., p.2

${ }^{46}$ Gordon, Michael: "Meddling Neighbors Undercut Iraq Stability", 5 December 2010, http:/www.nytimes.com/2010/12/06/world/middleeast/06wikileaks-iraq.html
} 
of the ruling Bahraini family. ${ }^{47}$ Most Turks supported the more secular Allawi during the elections, causing slight post-election tensions between Ankara and Maliki. However, growing Turkish influence in Iraq hasn't been objected by any major Iraqi political party. Furthermore, Turk officials have developed ties with moderate Kurdish leaders such as Jalal Talabani and Massoud Barzani. ${ }^{48}$

With the backing of the US, Iran and Moqtada Al Sadr, the Iraqi Prime Minister will most likely find himself cautiously toeing the line if he wishes to take a neutral stance on disputed issues between the rivals. The question remains whether Maliki will opt for political appeasement over pragmatic politics when approaching contentious topics such as US troop withdrawal from Iraq. Long-time rival and newfound kingmaker, Moqtada Al Sadr (who spent three years in voluntary political exile in Iran) now enjoys increased political leverage and several analysts believe that the Maliki-Al Sadr coalition could significantly guide the future of the country. However, this alliance will be extremely fragile as Sadr's supporters have vowed to withdrawal from Maliki's government if there is any attempt to keep a US military presence in Iraq beyond 2011. ${ }^{49}$

\section{Protests, Increasing Demands and Effects on Iraqi Governance}

Iraq's greatest threat may not come from violent extremists, meddling neighbors or an illequipped military; instead, high unemployment, poor basic services and lack of governmental cohesion could be the country's greatest enemy. Four out of five Iraqi's are under the age of 35 and half of the population is under 15. More than half of Iraqi youths are unemployed, and with a per capita income ranking $158^{\text {th }}$ in the world, most young Iraqis see little hope for their future. Furthermore, the county ranks 175 of 178 countries in Transparency International's Corruption Perception Index 2011, ${ }^{49}$ and the government's failure to put policy making over political maneuvering has resulted in citizens' basic needs going unattended.

A telling sign of Iraq's dire economic and budgetary troubles was seen in midFebruary 2011. A month earlier on December $14^{\text {th }}$, Iraq's COR authorized negotiations with the US for the purchase of six F-16 fighter jet planes. Shortly after, government spokesman, Ali al-Dabbagh, stated in a press conference that the COR had approved the purchase which would entail a $\$ 900$ billion down payment for the fighters which the US would deliver over the course of the next three years. Nevertheless, with civil unrest spreading throughout the Arab world, the COR quickly changed direction and on February $16^{\text {th }}$ it was announced that the $\$ 900$ billion would be directed towards the country's food rations programs which roughly 6 million Iraqis depend on. ${ }^{50}$

This event was significant for several reasons. First, it highlights the country's current long-term economic problems which have led to its dismal ranking in per capita income. Improving Iraq's economic situation will be a mighty task for the COR. However at the same

\footnotetext{
${ }^{47}$ The World This Week: The Economist, p. 8, April $2^{\text {nd }}-8^{\text {th }} 2011$

${ }^{48}$ Wietz, Richard, op cit., p. 2

${ }^{49}$ Ottaway, Marina: "Iraq: An Uneasy American-Iranian Condominium”, Carnegie Endowment for International Peace, 10 January 2011; Bazzi, Mohamad: “What Sadr's Return Means for Iraq”, Council on Foreign Relations, 6 January 2011

${ }^{49}$ The Corruption Perception Index measures the perceived levels of public sector corruption in 178 countries in the world. It can be viewed at http://www.transparency.org/policy_research/surveys_indices/cpi/2010/results
} 
time, the event also signaled that the government is showing signs of responsiveness to the people's struggles. This should be lauded. Unfortunately, Iraq's inability to purchase much needed armament and equipment that will protect its borders and counter domestic insurgent groups will force the country to be reliant on outside help in terms of security. The aircraft purchase would have helped put Iraq on path to controlling its airspace as the country currently depends on US assistance in this matter. This topic will be explored further on in the article. $^{50}$

\subsection{Civil Unrest}

In early February 2011, Iraqis began taking to the streets to demonstrate their dissatisfaction with current trends in the country. While the protests were not as large as those of Tunisia or Egypt, the demonstrations showed that even a democratically chosen government was susceptible to the revolts. The demonstrations were not homogenous as protesters in different regions organized independently and there was little spillover from one to another. However, the grievances were similar and centered on insufficient services (mainly electricity and food shortages) and government corruption. During Iraq's "Day of Rage", medium-size demonstrations took place in 10 different cities as citizens demanded action from both the central and regional governments. ${ }^{46}$

The protests would have been far larger had it not been for Moqtada Al-Sadr's abstention. Signaling a slight change in the contemporary political current, Al Sadr urged his large Shia following to stay home and give the government six months to address the problems. His followers obeyed. The Sadrist Trend is currently an important political entity which happens to reside over several service ministries. Therefore, it is not in their best interest to see the government weakened or fall. ${ }^{51}$

\subsection{Immediate Impacts}

Despite the smaller turnouts of the protests when compared to those in neighboring Arab countries, the demonstrations throughout Iraq had immediate effects. Initially Maliki blamed ex-Baathists for causing the unrest and warned that Al-Queda would exploit the situation. Stating security concerns, the prime minister imposed a curfew on vehicular traffic the night before the day of protests. Nevertheless, it didn't take long for Maliki to recognize the legitimacy of the demands. The COR's financial commission declared that the government would create 288,000 jobs once the budget was approved and Maliki announced that the government would make up for the shortage of food rations by allotting citizens a monthly stipend of about U.S \$12. Furthermore, in a symbolic gesture, Maliki reduced his yearly salary by half. He then announced that he would not run for a third term and would seek a constitutional amendment imposing a two-term limit of the position. The protests, which in some instances were violent, also triggered a wave of resignations of government and security officials at the provincial level. ${ }^{52}$

\footnotetext{
50 "Even a democracy is not immune", The Economist, 3 March 2011

${ }^{51}$ Schmidt, Michael: “Iraq's Top Shiite Leaders Urge Delay of Protests”, The New York Times, 23 February 2011

${ }^{52}$ The information in the paragraph and the following was drawn from: Ottoway, Marina; Anas Kaysi, Danial:

"Iraq: Protest, Democracy, and Autocracy", The Carnegie Endowment for International Peace, 28 March 2011 at http://www.carnegieendowment.org/publications/index.cfm?fa=view\&id=43306
} 
The impact of the protests went far beyond the visible government responses described above and will likely have a lasting impact on Iraqi governance in the near future. The demonstration put pressure on already strained and increasingly fragile political coalitions within the COR, and instead of coming together in an attempt to respond to the public anger, prominent politicians and figures engaged in a tit-for-tat blame game. The central government began to single out provincial officials and call for their resignation while provincial leaders deflected the public anger towards the central government. Grand Ayatollah Ali al-Sistani and ISCI leader, Ammar al-Hakim, openly criticized the government's handling of the protests and voiced their support those involved. Al-Sadr managed to distance himself from the Maliki by saying that the protesters' demands were legitimate; however, that they should give the government time to address the situation. If the government does not meet the people's demands within six months, Sadr stated that he will fully support them. ${ }^{53}$

The protests also resulted in a flare up of sectarian tensions. In late February, Arab and Turkmen planned protests in Kirkut to address corruption and unemployment in the region. Kurdish leaders took immediate action and warned that the protests would lead to attacks against the regional government. Dr. Najmaldin O. Karim, a member of the COR and Kurdish leader, stated that, "The Arab chauvinists were planning to destabilize Kirkut during the protests," and without hesitation in a unilateral act of defiance, Kurdistan President, Masoud Barzani, ordered 8,500 to 12,000 peshmerga troops to surround the city without consulting U.S. or Iraqi authorities. Kurdish officials claimed that the presence was necessary for added security in protecting the city from the "terrorist infiltrators." This exacerbated sectarian tensions in the city and was seen by Prime Minister Maliki as a direct violation to the joint security efforts in place in the disputed area. In a further attempt to deflect the anger away from local authorities, Kurd officials attempted to rouse nationalist sentiment throughout the region. On March $8^{\text {th }}$, Jalal Talabani, current President of the COR and Kurdish official, declared that Kirkut was "Kurdistan's Jerusalem" and called for a KurdishTurkmen strategic alliance against the "terrorists and new occupiers" of Kirkut. ${ }^{54}$

\section{Security Issues and Deadlines: Will Pragmatic Policymaking Trump Hard-Lined Politics?}

While the security situation in Iraq has improved drastically since the height of sectarian violence in 2007, the country continues to face pressing security issues. Currently, the Iraqi government and security forces rely heavily on assistance from the US As the December 31, 2011US military withdrawal quickly approaches, concerns have risen over post-withdrawal security throughout the country and several questions remain. Will the politically divided COR be able to come together to address the country's most urgent security needs, and will Iraqi politicians fulfil their campaign promises of putting citizen demands regarding security over sectarian politics? Furthermore, Maliki has not fully ruled out the option of an ongoing U.S. military presence of some capacity should the security situation warrant it. Will the increased role of anti-American factions like the Sadrist Trend force Maliki to stick to the

\footnotetext{
${ }^{53}$ Ibid., pp. 5-6

${ }^{54}$ Gunter, Michael: "New Tensions in Kirkuk as Kurdish Peshmerga Surround City”, The Jamestown Foundation, Terrorism Monitor Volume: 9 Issue: 13, 1 April 2011 at http://www.jamestown.org/single/?no_cache=1\&tx_ttnews\%5Btt_news\%5D=37735\&tx_ttnews\%5BbackPid $\% 5$

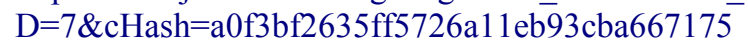


established U.S. troop withdrawal date, jeopardizing recent advances made under U.S. guidance?

To better understand the situation in Iraq and the challenges that Washington and Baghdad face, it is necessary to examine two key documents. The first is the Strategic Framework Agreement (SFA) which covers overall US political, economic, and security relationships with Iraq. The second is the 2008 US-Iraq Security Agreement, or Status of Forces Agreement (SOFA), which implements the US security relationship with Iraq. Both of these agreements were signed in November 2008 by the Bush Administration and the Council of Representatives in Iraq. The key difference between the two agreements is the binding legality that they present to the current situation. A recent U.S. State Department report described the SFA as an "aspirational document intended to broaden the US partnership with Iraq beyond security that is short on detail and non-binding." On the other hand, the same report describes the Security Agreement as the legal framework that dictates the terms of the American military presence in Iraq. The Security Agreement required US combat troops to withdrawal from Iraqi population centers by June 30, 2009, and more importantly, it obligates all US forces to leave Iraq by December 31, 2011, unless the Iraqi parliament requests an extension. ${ }^{55}$

\subsection{External Threats and Border Control}

While Iraq currently has no immediate external threats, border and airspace control have been under increased scrutiny with the US military withdrawal date approaching. Most analyst and military official predict that Iraq will need foreign assistance (most likely coming from the US) to secure its borders in the years to come. In addressing the shortages in border security, Prime Minister Maliki replied, "This is normal for a country whose armed forces were destroyed completely, no fighter jets, no artillery, and no tanks. I mean national security and security from the outside this needs more equipment. ${ }^{56}$

Most of Iraq's shortcomings derive from lack of personnel and equipment, which are often a result of the previously described budget troubles. A recent report to US Congress states that, "Although the Iraqi Army continues to make steady progress toward MEC (Minimum Essential Capabilities), ${ }^{57}$ it will not achieve a foundation for defense against external threats before December 2011 because of equipment procurement timelines and subsequent training requirements to complete development of four modern divisions (one mechanized and three infantry). Citing Iraq's budgetary shortfalls, the report later states that, "The trend of under-resourcing the Iraqi air force may lead to a gap in desired organic capacity in December 2011. The Iraqi Air force continues to expand its operational capability, but will not achieve MEC for airspace control., 58

\footnotetext{
${ }^{55}$ US Congress, Committee on Foreign Relations United States Senate. (2011). Iraq: the transition from a military mission to a civilian-led effort (63-954). Washington DC: US Government Printing Office at http://www.humansecuritygateway.com/documents/CFRUSSenate_Iraq_TheTransitionfromaMilitarytoaCivilian ledEffort.pdf

${ }^{56}$ Ibid., pp. 1

${ }^{57} \mathrm{MEC}$ is the term being used by the US Dept. of Defense to refer to a standard that indicates that forces "can provide internal security and possess foundational capabilities to defend against external threats"

58 "Measuring Stability and Security in Iraq" US Department of Defense (June 2010) at http://www.defense.gov/pubs/pdfs/June_9204_Sec_Def_signed_20_Aug_2010.pdf
} 


\subsection{Internal Security}

Iraq's internal security has improved drastically since the peak of sectarian violence in 2007 . As of December 31, 2010, the overall level of violence in Iraq was approximately $90 \%$ lower than its peak in 2007, and for the third consecutive month, December 2010 set a record for the fewest number of persons killed in attacks, down 151 from the previous month's 2010 record low of 171. While security incidents remain historically low, Iraq continues to face several internal security threats. Violent extremist networks continue to carry out attacks on civilians, government officials and security forces, ethno-sectarian tensions are ever-present, difficulties in integrating minority factions into security and governmental position remain, and a staggering economy and rampant unemployment have caused increasing civil unrest. ${ }^{59}$

\subsubsection{Insurgent Attacks and Extremist Groups}

Al-Qaeda in Iraq (AQI), Iraq's most prominent terrorist organization, and extremist groups continue to demonstrate their capabilities by carrying out attacks in an attempt to destabilize the country. In 2010, Iraqi-led, U.S.-supported operations continued to sustain pressure or extremist groups and were successful in capturing several top militant leaders. The US Department of Defense reported that as of June 2010, Iraqi and US forces killed or captured 34 of the top 42 AQI leaders, and unlike in past, extremist groups do not currently constitute and existential threat to Iraq's political order.

Estimates are inconsistent on the number of foreign fighters that are entering Iraq. The flow of foreign fighters into Iraq is at historical lows, and current estimates place AQI's makeup at 95\% Iraqi. However, more recent reports describe the number of foreign fighters in Iraq is increasing. Whatever the official number is, official in both Washington and Baghdad have expressed concern over increased funding to Al Qaeda in Iraq as the US prepares to withdraw. The most recent report to the members of the Committee on Foreign Relations of the US Senate, warned that the period immediately after the military withdrawal may be especially sensitive, as extremist groups test the new defenses and attempt to demonstrate their own relevance. Furthermore, there is concern that continued political instability could benefit extremists and provide them with an opportunity to gain ground. ${ }^{60}$

\subsubsection{Ongoing Sectarianism}

When establishing the benchmarks that would measure Iraq's political progress, both Washington and Baghdad agreed that serious political reconciliation amongst Iraqi groups would be needed to reduce violence and create a viable government. As a priority, in $2006 \mathrm{~A}$ Constitutional Review Committee (CRC) was set up to propose amendments to the 2005 Constitution, which many Iraqis saw as an American-architected compact between Shias and Kurds. The CRC would engage Sunni negotiators in the process. Several key benchmarks of political progress are tied to the ongoing constitutional reform. An April 2011 Report for US Congress states that the CRC filed a final report in August 2008 but major issues remain unresolved and require achievement of consensus among major faction leaders. ${ }^{61}$

\footnotetext{
${ }^{59}$ Cordesman, Anthony: "Iraq: Patterns of Violence, casualty Trends and Emerging Security Threats", Center for Strategic and International Studies, 9 February 2011

${ }^{60}$ Committee On Foreign Relations United States Senate op cit., p. 4

${ }^{61}$ Katzman op cit., p. 30
} 
Sectarian divides ran deep during the government formation period; however, in the end, deals were brokered and alliances, albeit fragile, were made to form the current COR. To the relief of many, ethnic tensions did not provoke retributive sectarian violence like in past years. Nevertheless, core challenges to national unity remain, including contentious hydrocarbon laws, internal boundary disputes between Arabs and Kurds and integrating minority factions like the Sons of Iraq and the Kurdish peshmerga (military forces) into and security forces. Furthermore, sectarianism and separatism continue to challenge Iraqi political and threaten national stability.

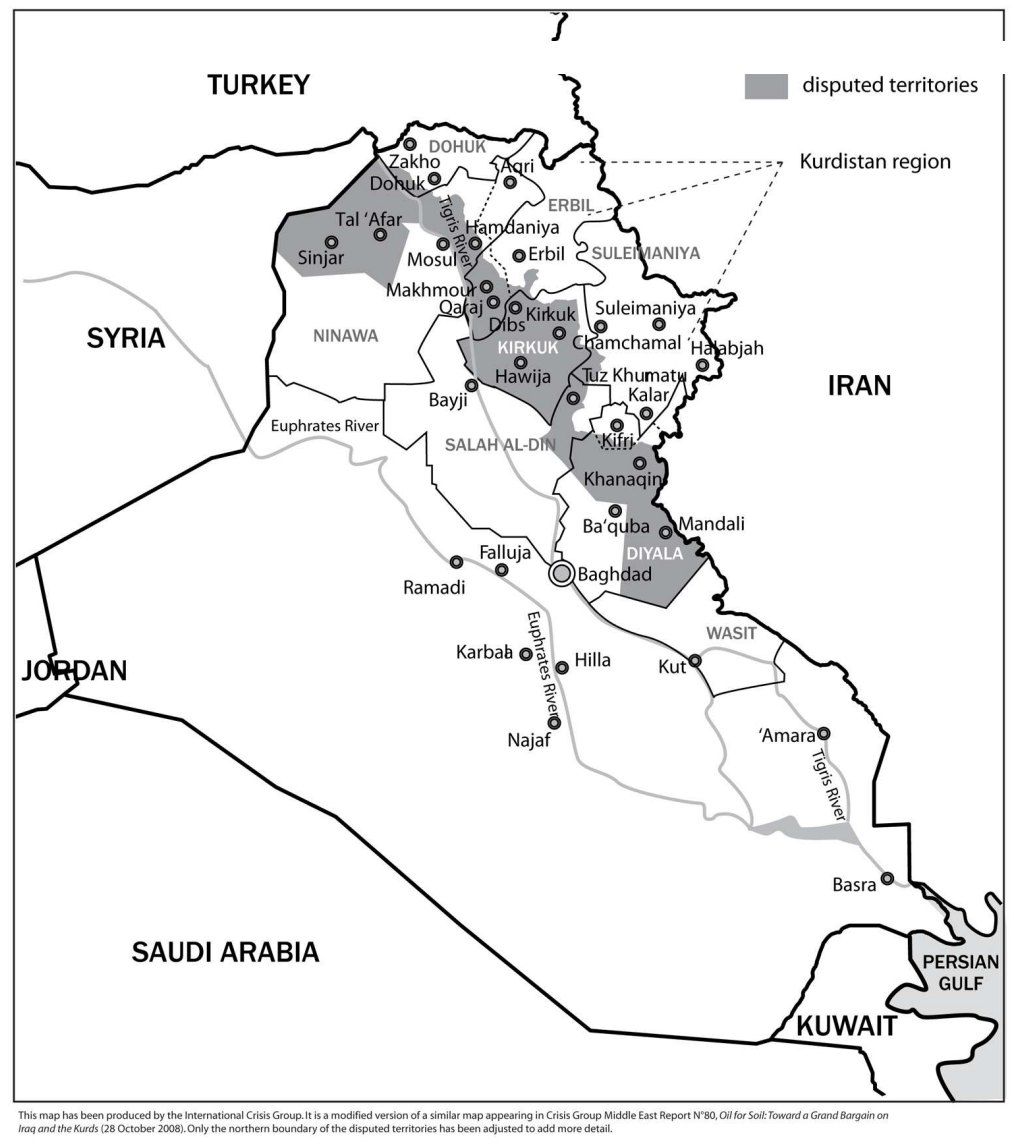

\subsubsection{Arab-Kurd Tensions}

Arab-Kurd tensions have taken center stage as of late. The approach that the Iraqi government uses to calm these disputes could determine the future of the country. Two key issues regarding security are the disputed internal boundaries between Arab and Kurdish regions and the integration of Kurdish security forces into Iraqi Security Forces. Bilateral progress between Baghdad and the Kurdistan regional government (KRG) in confronting pressing issues has been slow and remain heavily reliant on the US and the UN to mediate disputes and secure the region. Furthermore, sectarian tension has risen throughout early 2011, concerning all parties involved as the US troop withdrawal date nears. A report published in early April 2011 by the United States Institute of Peace described the situation as the greatest threat to Iraq's stability, beyond that of terrorist groups such as Al Queda. ${ }^{62}$

The territorial dispute over oil-rich Kikuk, the name for three separate but overlapping entities - city, governorate and oil fields - is central in Arab-Kurd tensions. Kirkuk and several other cities in the region are ethnically mixed between Arabs, Kurds and Turkmen. As previously described, the region has been prone to political jockeying via population relocation in the past, causing controversy over voting rights come election time. The ethnopolitical tensions over the disputed territories have gone largely unresolved. The nine-month political impasse largely revolved around which party would meet the Kurds' 19 demands and topping the list was the implementation of the 2005 constitution which, as the Kurds see it, should result in the incorporation of Kirkut and other disputed territories into the Kurdistan region. After gaining Kurd support to form a government, Prime Minister Maliki signaled that

\footnotetext{
${ }^{62}$ Arango, Tim: "Kirkut Tensions Highlight Concerns Over U.S. Troop Exit", The New York Times, 7 April 2011 at http://atwar.blogs.nytimes.com/2011/04/07/kirkuk-tensions-highlight-concerns-over-u-s-troopexit/?pagemode=print
} 
he was willing to agree to most of the power-sharing claims. However, this is likely to be a slow moving process, and many analysts remain skeptical of the government's ability to realize tangible advances. In a recent interview, Maliki pointed out that redrawing the borders of a province would need a decree from the presidential council and approval by parliament. Given the COR's recent inability to achieve effective legislation in a relatively short period of time, the territorial disputes (along with the regional census legislation) will not likely be resolved in the near future. ${ }^{63}$

In an effort to ease tension and prevent violent conflict, in 2009 the US military established 'Combined Security Mechanisms' in which Arabs, Kurds, and American security forces operate checkpoints and conduct joint patrols in four provinces along the Arab-Kurd trigger line (the line of control between the Iraqi army and the Kurdish peshmerga that runs along the disputed region's border). The Combined Security Mechanisms have been successful in reducing violent attacks along the disputed internal boundaries. In 2007, the Kirkuk police and Ministry of Interior reported 919 roadside bombs in Kirkuk, while in 2010 the number was reduced to 142 . However, as the US military draws down, sectarian tensions and increased concern have surfaced and many doubt that the Iraqi Government will be able to maintain the integrated security along the internal border region once US troops withdrawal. The US State Department has stated that the US military presence is "the glue" that holds together cooperation between the Iraqi army and Kurdish peshmerga, leading several Kurdish officials to call for a prolonged US military presence. ${ }^{64}$

\subsubsection{Pending Oil Legislation}

A key issue in the disputes between Baghdad and the KRG is the Kurds' ability to export oil that is discovered and extracted in the KRG region. Oil exports from the KRG have been suspended since late 2009. While the Kurds want Baghdad to use part of their petroleum revenues to pay international investors and companies that are performing the extraction and exportation in the north, the southern and central regions of the country are pressing revenues to go towards greater social services. ${ }^{65}$ According to Denise Natali, a specialist in Kurdish issues at the Institute for National Strategic Studies, "The 2005 Constitution - which, in an attempt to prevent a tyranny of the majority - left revenue and resource-sharing between Baghdad and its provinces unclear, which in turn undermined the viability of development projects." ${ }^{66}$ Iraq's economy will depend on future oil production. Oil laws that ensure equitable distribution of resources continue to be stalled in the COR and enacting and implementing them accordingly will take great political will in an attempt to get Iraq's economy and development efforts on the right track.

\subsubsection{Sunni Marginalization and the Sons of Iraq}

Sunni-Shia tensions escalated after the removal of the Hussein regime, resulting in an eventual civil war that cost the lives of thousands. In an attempt to avoid Sunni marginalization and increased Iranian influence over the Shia-dominant political parties in Iraq, the US continuously called for an all-inclusive government that represents the country's electorate. The Sunni Awakening, a movement comprised of Sunni tribal leaders who recruited the "Sons of Iraq" (SOI) fighters was seen as a pivotal step towards increased Sunni

\footnotetext{
${ }^{63}$ Iraq and the Kurds: Confronting Withdrawal Fears, International Crisis Group, Middle East Report No 103,28 March 2011

${ }^{64}$ US Congress, Committee on Foreign Relations United States Senate op cit., p.6

65 Katzman, op cit., p. 18

${ }^{66}$ Natalie, Denise: "Iraq's Petroleum Impasse”, Arab Reform Bulletin, 2 March 2011
} 
integration into national political and security apparatuses. The movement has been largely credited for turning Iraqi Sunnis against Al Qaeda-linked extremists in Iraq.

Sunni tribes largely abstained from the December 2005 elections as their attention was focused primarily on the severe violence in the Sunni provinces (particularly Anbar). This led to further marginalization and political disenfranchisement of the Sunni population. The 2009 provincial elections saw increased Sunni political participation, leading many to hope that the Awakening movement would become a political force in empowering Sunnis. However, the March 2010 parliamentary elections were a serious setback to the Sunni Awakening movement. The movement presented little political organization and suffered from infighting and internal divisions during the run-up to the elections. ${ }^{67}$

As U.S. Vice President Joe Biden stated in his November 2011 letter, further Sons of Iraq integration into the ISF will be integral to Sunni integration efforts. As of January 2011, about half of the SOI (about 50,000) have been integrated into the ISF or given the civilian government jobs they were promised. The process has proven to be slow and negative perceptions have surfaced among the SOI. Furthermore, the Sunni community remains concerned about SOI leader arrests, attacks by AQI insurgents, late payment of salaries, and halted transitions to permanent government jobs. ${ }^{68}$

The SOI transition throughout 2010 was marked by government pay freezes that resulted in defection by SOI fighters in large numbers. Should this continue, an incomplete integration process could have serious repercussions on Iraqi security and sectarian violence. SOI fighters have taken on increased risks and the wake of the 2010 elections saw a string of attacks and assassinations against Awakening members, including the killing of more than 40 people by a single suicide bomb in Baghdad. Throughout October and November 2010, there were 34 attacks against the SOI that resulted in 17 deaths. These increased attacks, coupled with the failure to be paid for their work, have resulted in the resignation of thousands of Awakening fighters. This has caused great concern as reports have surfaced that hundreds of fighters appear to have rejoined Al Qaeda. ${ }^{69}$

\section{An Ongoing US Troop Presence?}

There are currently around 47,000 US military troops in Iraq, all of which are scheduled to withdrawal from the country by the end of December 2011, as stated in the US-Iraq Security Agreement. These troops carry out a non-combative role, largely assisting and training the Iraqi Army and the Iraqi Security Forces. Most analysts believe that extended US military presence in the continued training and capacitating of Iraqi Security Forces, as well as acting as a mediator for internal disputes, would be beneficial for the country.

The December 31, 2011 US troop withdrawal date has become an increasingly polarized topic both in Baghdad and along the Beltway. Most experts agree that the Iraqi government will not be fully capable of overtaking full security responsibilities by the established date. Military officials in both countries have stated that the date should be postponed to assure maximum Iraqi capacity; however, while not entirely out of the question,

\footnotetext{
${ }^{67}$ Katzman, K., op. cit., 17

68 "Awakening movement in Iraq", The New York Times 19 October 2010

${ }^{69}$ Cordesman, Anthony: "Iraq: Patterns of Violence, Casualty Trends and Emerging Security Threats", Center for Strategic and International Studies, 9 February 2011
} 
a bi-lateral agreement that would extend US military presence seems to be unlikely. Prime Minister Maliki is in a no-win situation. Maliki has clearly stated that the withdrawal of all US troops is scheduled for December 31, 2011, and that is when the last American soldier will leave. However, Maliki did mention that an extension to the agreement would be possible, but only if the new government with parliament's approval wanted to reach a new agreement with Washington. ${ }^{70}$ Given the dynamics of the new COR, this will be unlikely as many politicians and prominent leaders see a continued U.S. presence as an infringement to Iraq's sovereignty. Moqtada Al Sadr and his political block have vowed to withdrawal from Maliki's government if the prime minister attempts to keep US forces in Iraq beyond December 2011.

The Iraqi Army and Security Forces are predicted to fall short of several Minimum Essential Capabilities by December 2011. The US State Department projects that security gaps will remain in logistics, maintenance and sustainment, cross-ministerial intelligence and information sharing, conventional defense capabilities of the army, transition to police primacy and control of airspace and enforcement of air sovereignty. From Washington's perspective, recent successes are largely due to the less visible role that US security forces carry out on a daily basis. A January 2011 State Department reports states: "Complicating matters, Iraq's political leadership may not fully appreciate how integral U.S. military support is to buttressing the Iraqi army's basic capabilities. In large part operating behind the scenes, American troops still provide critical administrative and logistical functions, skills the Iraqi forces have yet to master." ${ }^{, 71}$ Additionally, it is widely recognized that US forces are playing an integral role in calming sectarian tensions throughout Iraq. The Combined Security Mechanisms put in place to ease Arab-Kurd tensions are a prime example, and the Kurds have long advocated an extended US presence. Recently, Nahida al-Dainni, a Member of Parliament from Iraqiyya, voiced his concern over the disputed territories: "This area will be a civil war if U.S. troops leave," he stated. ${ }^{72}$

\subsection{Gates's April Visit}

Recent events have indicated the realities of security concerns in Iraq and the complicated politics that will accompany policymaking decisions in the near future. In early April 2011, US Defense Secretary Robert Gates visited US forces in Iraq. During his visit, Gates made public which has up until now been private talk. The Defense Secretary stated that US troops could stay in Iraq well beyond the December 2011 deadline, carrying out what he described as an "assist and advise" role. ${ }^{73}$ Maliki has not yet signaled whether or not he is leaning towards an extension of US military presence. Under the terms of the security agreement, the Iraqi government would have to ask the United States to extend its presence. Should Baghdad seek an extension, the petition would have to be made soon as US forces are currently planning for their withdrawal by the end of the year.

The current security situation combined with the new dynamics of the COR puts Maliki in a very tough situation and could jeopardize national stability in the near future. While Secretary Gates visited US troops throughout Iraq, followers of Moqtada Al-Sadr (mostly Shia underclass) took to the streets demanding an end to American military presence. Sadr sent a message to the crowd stating that he would reconstitute his militia, the Mahdi

\footnotetext{
${ }^{70}$ Wall Street Journal, op cit., p.3

${ }^{71}$ Committee On Foreign Relations United States Senate, op. cit., p. 5

${ }^{72}$ Bumiller, Elisabeth; Arango, Tim: “Gates Says Some Troops May Remain in Iraq for Years”, The New York Times, 8 April 2011

${ }^{73}$ Ibid., p 1
} 
Army, if the American military did not leave at the end of this year. The anti-American Shia cleric that was behind much of the sectarian violence during the years of civil war made it clear that a US troop extension will be met with military resistance. ${ }^{74}$ Had it not been for Sadr's support, Maliki would not be Prime Minister. So the Iraqi parliament must now choose between extending a moderate US troop presence that would continue to carry out an "assist and advise" role, or appease Sadr and other hardliners and stick to the established timeline, leaving the Iraqi state to take full responsibility of security matter, regardless of MEC statuses.

\section{Conclusion}

Iraq has made great strides in recent years in transitioning from an autocratic state to an allinclusive representative democracy. The March 2010 parliamentary elections were a major step towards increased political participation across ethnic lines, and while a political stalemate ensued, insurgents were not able to capitalize on the situation by tearing the country apart along sectarian lines. Security has drastically improved in recent years, and many analysts have praised the Iraqi government and security forces for dealing with the recent protests far better than many of their Arab neighbors. Nevertheless, While Iraq has made significant progress on several fronts, the country continues to be politically unstable and several questions remain unanswered:

1) What short and long-term effects will the recent protests have on Iraq's regional and national government? Will politicians now make greater attempts in improving the livelihood of their constituents, or will they continue the corrupt practices that caused many of the protests in the first place?

2) Insurgents continue to carry out attacks on civilians, government officials and security forces. What effects will these attacks have on internal stability, and what steps will the COR take to increase security throughout the country?

3) As time ticks away, how will the COR confront the US troop withdrawal deadline? Will political factions put ideological differences aside and ask for an extended US presence where needed?

4) How will the Iraqi government tackle the pending big issues that will determine the future of the country? Several advances must still be made regarding issues such as oil revenue sharing, disputes over contested territories, integration of Kurds and Sunnis into security forces, the ongoing debaathification process, etc.

5) How will regional actors continue to influence stability in Iraq?

6) And finally, to what extent will Iraq's economic and budgetary problems continue to undermine security throughout the country?

\footnotetext{
${ }^{74}$ Arango, Tim; Ali D. Khalid: "Iraqis Protest U.S. After Comments From Gates", The New York Times, 9 April 2011
} 
Since March of 2010, Iraqi politics has been marked by an ongoing political chess match directed by party leaders with personal interests, sacrificing any hope for pragmatic policymaking. Iraq's political, economic and security struggles will only be resolved if the COR can effectively put policy making over sectarian politics and pass essential legislation regarding the key issues previously described. This will not be easy and given the recent upsurge in blame-game politics, it might not be likely. The Iraqi people's patience is running thin and demands will continue if results are not produced. If the central and regional governments continue to fail their constituents, we can expect an increasingly volatile and unstable Iraq in the near future. Or, the military forces, which are increasingly fed up with the political instability and lack of political solutions, could end up restructuring the political system. 